\title{
The use of toxicokinetics and exposure studies to show that carprofen in cattle tissue could lead to secondary toxicity and death in wild vultures
}

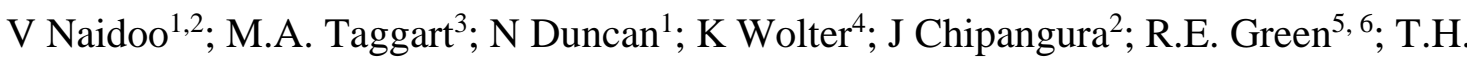 \\ Galligan 6
}

${ }^{1}$ Department of Paraclinical Sciences, Faculty of Veterinary Science, University of Pretoria.

${ }^{2}$ Biomedical Research Centre, Faculty of Veterinary Science, University of Pretoria

${ }^{3}$ Environmental Research Institute, University of the Highlands and Islands, Castle St, Thurso, Scotland, KW17 7JD

${ }^{4}$ VulPro, Plot 121, Rietfontein, 0048, South Africa

${ }^{5}$ RSPB Centre for Conservation Science, David Attenborough Building, Cambridge, Cambridgeshire, CB2 3QZ, UK

${ }^{6}$ Conservation Science Group, Department of Zoology, University of Cambridge, David Attenborough Building, Cambridge, Cambridgeshire, CB2 3QZ, UK

\begin{abstract}
Veterinary medicines can be extremely damaging to the environment, as seen with the catastrophic declines in Gyps vulture in South Asia due to their secondary exposure to diclofenac in their primary food source. Not surprisingly, concern has been raised over other similar drugs. In this study, we evaluate the toxicity of carprofen to the Gyps vulture clade through plasma pharmacokinetics evaluations in Bos taurus cattle (their food source) and Gyps africanus (a validated model species); tissue residues in cattle; and the effect of carprofen as a secondary toxicant as both tissue-bound residue or pure drug at levels expected in cattle tissues. Carprofen residues were highest in cattle kidney $(7.72 \pm 2.38 \mathrm{mg} / \mathrm{kg})$ and injection site muscle $(289.05 \pm 98.96 \mathrm{mg} / \mathrm{kg}$ of dimension of $5 \times 5 \times 5 \mathrm{~cm})$. Vultures exposed to carprofen as residues in the kidney tissue or pure drug equivalents showed no toxic signs. When exposed to average injection site concentrations $(64 \mathrm{mg} / \mathrm{kg})$ one of two birds died with
\end{abstract}


evidence of severe renal and liver damage. Toxicokinetic analysis revealed a prolonged drug half-life of $37.75 \mathrm{~h}$ in the dead bird as opposed to $13.99 \pm 5.61 \mathrm{~h}$ from healthy birds dosed intravenously at $5 \mathrm{mg} / \mathrm{kg}$. While carprofen may generally be harmless to Gyps vultures, its high levels at the injection site in treated cattle can result in lethal exposure in foraging vultures, due to relative small area of tissue it is found therein. We thus suggest that carprofen not be used in domesticated ungulates in areas where said carcasses are accessible or provided to vultures at restaurants. 


\section{Introduction}

The harm that veterinary medicines can cause to the environment, not only directly via spillage, runoff and poor disposal practice, but also indirectly via excreta and residues in animal tissue has only recently been acknowledged (Arnold et al., 2014, Margalida et al., 2014, Kuster and Adler, 2014). Of these pathways, residues of veterinary medicines in animal tissues have usually been considered only of importance to human health. However, veterinary medicine residues in animal tissues can be toxic to any species consuming them, particularly if that species is highly intolerant to the medicine concerned or is exposed to said medicine at high concentrations or for prolong periods.

One veterinary medicine that is known to harm wildlife is the non-steroidal antiinflammatory drug (NSAID) diclofenac. Recognised as an environmental toxicant, diclofenac entering waterways can cause toxicity in fish (Schwaiger et al., 2004). However, the greatest impact diclofenac has had on wildlife is as the primary cause of population declines in several species of Gyps vulture resident to South Asia (Oaks et al. 2004, Green et al., 2004, 2007; Prakash et al., 2007). Gyps vultures are highly intolerant to diclofenac, showing acute renal failure and death at doses at or below $0.8 \mathrm{mg} / \mathrm{kg}$ body weight (Oaks et al., 2004, Swan et al., 2006). Vultures are exposed to diclofenac residues in tissues of livestock that have been treated shortly before death and then left for vultures to consume. The use of diclofenac in palliative care of cattle among Hindu communities and the fact that cattle constitute the primary source of food for vultures in South Asia, resulted in population declines in vultures of up to $99.9 \%$ (Prakash et al., 2007).

Experiments have shown that a second NSAID, ketoprofen, is also toxic to vultures (Naidoo et al., 2010a, Naidoo et al., 2010b), whereas a third NSAID, meloxicam, is not (Swan et al., 2006, Swarup et al., 2007). All three NSAIDs belong to different chemical 
classes and the reason that two of these three are toxic to vultures remains unknown.

However, vulture intolerance may be linked to zero-order elimination (Naidoo et al., 2010b). More importantly, with toxicity resulting from oral exposure, it is suspected that metabolic capacity at the level of the pre-systemic metabolic system drives exposure and subsequent toxicity. As a result, much concern has been raised over the large number of untested NSAID compounds available for veterinary use in South Asia and other regions where Gyps vultures range (i.e., Africa and Europe). One of these untested NSAIDs is carprofen, which is widely used in veterinary medicine and is recommended for use in many taxa, including raptors (Richman and Hayward, 2011).

A recent study exposed two Cape griffon (Gyps coprotheres) to carprofen by the oral route at the recommended veterinary dose of $10 \mathrm{mg} / \mathrm{kg}$ body weight (Fourie et al., 2015). While no overt toxicity was detected, the two vultures had substantially different pharmacokinetic profiles, suggesting that zero-order metabolism and the potential for toxicity in susceptible Gyps vulture individuals is possible. Further, concentrations of carprofen in animal tissues consumed by vultures may be greater than the concentration of carprofen in the therapeutic dose tested.

For this study, we further explore the toxicity of carprofen to Gyps vultures. We report studies of the pharmacokinetics and maximum residue levels of carprofen in Bos taurus cattle; calculate the maximum residue exposure (MRE) for carprofen to wild Gyps vultures; and harvest carprofen-rich cattle tissues to provision Gyps vultures under controlled experimental conditions. Unfortunately, with clear evidence of toxicity in vultures currently being limited to Gyps (although other old world species may also be vulnerable), the only method available for elucidating the toxic potential of various NSAIDs is to undertake in vivo toxicity studies with a Gyps species. However, studies are enhanced when combined with the 
pharmacokinetic/toxicokinetic evaluation of the drug under investigation to determine if it is characterised by a prolonged half-life of elimination.

\section{Methods}

Research permission

Permission to undertake the study was given by the Research Committee of the Faculty of Veterinary Sciences, University of Pretoria, and the Animal Ethics Committee of the University of Pretoria (V062-13). Permission to work on an endangered species (Gyps africanus) was approved by the South African Department of Environmental Affairs (Permit 07137).

\section{Cattle test subjects}

Bos taurus cattle were used in a pharmacokinetics study and a tissue residue study. Four female mixed-breed cattle 15-18 months of age were used in the pharmacokinetics study; and four female Friesian cattle 9 months of age were used in the tissue residue study. Cattle were acquired from commercial livestock owners in Pretoria, South Africa. Initially, they were kept under non-treatment quarantine in outdoor camps of the University of Pretoria for six of seven weeks prior to experimentation to ensure they were free of NSAIDs and other drugs. Then cattle were moved to temperature-controlled stables at the Biomedical Research Centre, University of Pretoria, for the last week before experimentation. Cattle were given food, water, bedding and exercise daily. During the acclimatisation period each animal received a complete veterinary examination and was deemed fit and healthy. Throughout the study, each animal was monitored by a veterinarian or animal technician for signs of adverse drug reactions, but none were detected. At the completion of the pharmacokinetics study, the cattle 
were returned to their owners with an enforced three-month withdrawal period. At the completion of the tissue residue study, the cattle were terminated within the pathology facilities.

\section{Vulture test subjects}

White-backed vultures (Gyps africanus) were used in a pharmacokinetics study $(\mathrm{n}=6)$ and toxicity study $(\mathrm{n}=8)$. This species was selected as it is a validated surrogate species for Asian Gyps vultures in NSAID toxicity studies, having been found to be killed by low oral doses of diclofenac (Swan et al. 2006). Some of the vultures used in the pharmacokinetic study were also used in the toxicity study. All vultures originated from the wild, each had been rescued and treated for illness and injuries at VulPro, South Africa, within six months of the start of the experiment. During that time, the vultures were kept in large communal aviaries at VulPro, where they were provided with water, food (every three days), perches and the room for short flapping flight. Each received a complete veterinary examination and was deemed fit and healthy. Three days prior to experimentation, vultures were moved to individual holding aviaries (dimensions: $3 \times 2 \times 2 \mathrm{~m}$ ) also at VulPro. At the completion of both studies, the vultures were returned to large communal aviaries.

\section{Pharmacokinetic study in cattle}

On the first day of this study, each cow was weighed (mean $\pm \mathrm{SD}=413.25 \pm 40.6 \mathrm{~kg}$ ); and a $10 \mathrm{ml}$ sample of blood was collected from its jugular vein into an evacuated heparinised tube. Next, each cow was treated with carprofen (Norocarp, Norbrook South Africa) at the standard cattle dose of $1.4 \mathrm{mg} / \mathrm{kg}$ bw and further blood samples were collected in evacuated heparin tubes at $0.25,0.75,1.50,2.00,3.00,5.00,7.00,9.00,12.00,24.00,36.00,48.00$, 
96.00 and $120.00 \mathrm{~h}$ after treatment. Within $2 \mathrm{~h}$ of collection, all blood samples were centrifuged at $\sim 3,000 \mathrm{~g}$ for $15 \mathrm{~min}$ and the supernatant (plasma) was transferred to a glass screw-top vial and immediately frozen at $-80{ }^{\circ} \mathrm{C}$.

\section{Pharmacokinetic study in Gyps vulture}

Vultures $(n=6)$ were assigned to three groups of two birds each, with each pair being subsequently treated with carprofen (Norocarp) at $5 \mathrm{mg} / \mathrm{kg}$ bw by the intramuscular injection; intravenous injection or by oral gavage. Blood samples $(5 \mathrm{ml})$ were collected from the tibiotarsal vein into sterile syringes before treatment and at 1.00, 2.00, 4.00, 6.00, 8.00, 12.00, $24.00,36.00$ and $48.00 \mathrm{~h}$ after treatment. Immediately after collection, half of each sample was transferred into evacuated heparinised tubes for carprofen analysis, and, the second half was transferred into non-treated evacuated tubes for biochemistry analysis. Samples were processed as for the cattle pharmacokinetic study and stored at $-30^{\circ} \mathrm{C}$.

\section{Tissue residue study in cattle}

On the first day of this study, each of the four study animal was weighed (mean $\pm \mathrm{SD}=$ $207.25 \pm 31.89 \mathrm{~kg}$ ) and treated with carprofen (Norocarp) at $2.8 \mathrm{mg} / \mathrm{kg}$ bw in a single dose. The reason for doubling the dose was to simulate the behaviour of veterinarians and livestock owners in South Asia. Measured NSAID residues in tissues of dead cattle indicate that they have often received much more of the drug than the recommended dose of NSAIDs in palliative care of cattle (see Taggart et al. 2007). At $12 \mathrm{~h}$ after treatment, which corresponded to the mode $\mathrm{T}_{\max }$ (as informed by the pharmacokinetic study undertaken previously), the cattle were slaughtered by captive bolt and pithing. The liver, kidneys, muscle from the hind leg, omental fat and muscle from the injection site in the neck (i.e., a $5 \mathrm{~cm}$ area surrounding 
the injection site, to a depth of $5 \mathrm{~cm}$ ) were harvested. Three replicate sub-samples were taken of each tissue (except for the injection site) and stored at $-30{ }^{\circ} \mathrm{C}$ prior to analysis. Remaining bulk tissue was also stored at $-30^{\circ} \mathrm{C}$ for the final phase of the study which involved feeding vultures with harvested tissues.

\section{Toxicity study in Gyps vultures}

Toxicity was determined with a four-phase cross-over study. Each phase was separated by two weeks when vultures were returned to their communal aviaries. Vultures were randomly assigned to one of two balanced groups: Group A ( $n=4)$; and Group B ( $n=4)$. In Phase 1, Group A were given approximately $1 \mathrm{~kg}$ of kidney tissue rich in carprofen residues from the cattle slaughtered in the residue study (a single vulture received kidney tissue from a single cow). Group B were given approximately $1 \mathrm{~kg}$ of cattle kidney tissue which was purchased from a commercial butchery. According to South African legislation, butchered meat should comply with Codex Alimentarius standards for food safety and, therefore, unlikely to be contaminated with NSAIDs.

In Phase 2, Group B were given muscle tissue rich in carprofen residues (harvested from previously dosed cattle); and Group A were given pig muscle tissue acquired from a commercial piggery that confirmed that no NSAIDs were used in the pigs prior to death. For both Phases 1 and 2, the carprofen-rich tissues were frozen at $-30{ }^{\circ} \mathrm{C}$ after harvesting and then thawed in a water bath at room temperature the night before use. Carprofen-free tissues were purchased fresh and held refrigerated at $4{ }^{\circ} \mathrm{C}$ overnight before use.

In Phase 3, Group A were given carprofen orally at a level based on the theoretical maximum residue exposure (MRE) calculated from the cattle kidney concentrations (see below); and Group B were given water. 
In Phase 4, two vultures randomly selected from Group B were given carprofen orally at the average concentration found within the injection site tissues; and two vultures randomly selected from Group A were given carprofen orally at the MRE calculated from the cattle kidney concentrations. The use of two vultures for toxicity prediction, was as previously validated by Swan et al (2006b).

Blood was sampled from all vultures in Phase 3 and Phase 4 before and at 2.00, 8.00, 24.00 and $48.00 \mathrm{~h}$ after treatment for toxicokinetic and clinical pathology analyses as described above. Sampling was not attempted in Phase 1 and Phase 2 as it might have resulted in vultures regurgitating tissues. For comparative purposes, the expected blood parameter ranges for normal vultures was estimated only from samples taken from the control group in Phase 3.

\section{Plasma and tissue analysis}

All cattle and vulture plasma and tissue samples were couriered on dry ice to the Environmental Research Institute (ERI), United Kingdom. A subsample of each ( $0.3 \mathrm{ml}$ for plasma or $0.5 \mathrm{~g}$ for tissue) was extracted using $2.5 \mathrm{ml}$ of HPLC grade acetonitrile. For plasma this was done by vortex mixing (20 s), then setting to stand at room temperature (600 s), then vortex mixing (20 s), and finally centrifuging at $2000 \mathrm{rpm}(671 \mathrm{~g} ; 600 \mathrm{~s})$. For the tissue this was done by homogenising with a VDI 12 (VWR) homogeniser, then centrifuging as per the plasma. The supernatant was, in both cases, syringe filtered $(0.2 \mu \mathrm{m}$ HDPE disposable) directly into an amber $2-\mathrm{ml}$ screw top LC vial. These extracts were held at $-20{ }^{\circ} \mathrm{C}$ until analysis. Carprofen concentration was determined using a liquid chromatography electrospray ionisation triple quadrupole mass spectrometry system (LC-ESI-MS/MS) utilising a methodology adapted after Taggart et al. (2009). Carprofen was determined in 
negative ion mode utilising a parent target mass of $272 \mathrm{~m} / \mathrm{z}$ and a daughter ion of $228 \mathrm{~m} / \mathrm{z}$ (in MRM mode). Mean recovery of carprofen spiked in triplicate into blank plasma and liver tissue at three different concentration levels and extracted as above was $79.4 \%$ and $70.6 \%$ respectively ( $\mathrm{n}=9$ in both cases) and the limit of quantification for the analysis was $4 \mathrm{ng} / \mathrm{ml}$ and $10 \mathrm{ng} / \mathrm{g}$ for plasma and tissue respectively. Final concentrations were calculated following correction for these extract recovery levels.

\section{Pharmacokinetics/Toxicokinetic evaluation}

For both cattle and vulture plasma samples, pivotal parameters were ascertained by noncompartmental modelling in Kinetica 5.1 (Thermo 2012). The maximum plasma concentration $\left(\mathrm{C}_{\max }\right)$ and the time to reach it $\left(\mathrm{T}_{\max }\right)$ were read from the plasma concentration versus time profile. The last quantifiable time point $\mathrm{C}_{\text {last }}$ and the linear trapezoidal rule was used to calculate the area under the curve (AUClast) and the area under the moment curve $\left(\mathrm{AUMC} C_{\text {last }}\right)$ as $\left(\mathrm{AUC}_{\text {last }}=\Sigma\left(\left[\mathrm{T}_{\text {last }}-\mathrm{T}_{\text {last }-1}\right] *\left[\mathrm{C}_{\text {last }}+\mathrm{C}_{\text {last }-1]}\right] / 2\right)\right)$ and $\left(\mathrm{AUMC}_{\text {last }}=\Sigma\left(\left[\mathrm{T}_{\text {last }}-\mathrm{T}_{\text {last }}\right.\right.\right.$ $\left.\left.\left.{ }_{1}\right] *\left[\mathrm{~T}_{\text {last }} * \mathrm{C}_{\text {last }}+\mathrm{T}_{\text {last }-1} * \mathrm{C}_{\text {last-1 }}\right] / 2\right)\right)$, respectively. The elimination rate constant $(\lambda)$ was calculated by ordinary least squares regression of the terminal three points of the curve after natural logarithmic transformation; and subsequently, the half-life of elimination ( $\left.\mathrm{T}_{\text {half }}\right)$ was calculated as $\ln (2) / \lambda$. The mean residence time (MRT) was calculated as AUMC/AUClast and the area under curve to infinity ( $\left.\mathrm{AUC}_{\mathrm{inf}}\right)$ was calculated as $\mathrm{AUCl}_{\text {last }}+\mathrm{C}_{\text {last }} / \lambda$. For carprofen administered intramuscularly and orally, the apparent volume of distribution $\left(\mathrm{V}_{\mathrm{z}} / \mathrm{F}\right)$ was calculated as dose/(AUClast $* \lambda)$, the apparent volume of distribution at steady state $\left(\mathrm{V}_{\mathrm{ss}} / \mathrm{F}\right)$ was calculated as $\left(\right.$ dose $\left.^{*} \mathrm{MRT}\right) / \mathrm{AUC}_{\text {last }}$ and the apparent clearance $(\mathrm{Cl} / \mathrm{F})$ was calculated as dose/AUClast; and for carprofen administered intravenously, the actual volume of distribution $(\mathrm{Vz})$, actual volume of distribution at steady state $\left(\mathrm{V}_{\mathrm{ss}}\right)$ and actual clearance $(\mathrm{Cl})$ were 
calculated by first finding the fraction of absorption $(\mathrm{F})$ and dividing this by the apparent measures of these parameters. F was calculated as a bird's extravascular AUCinf divided by the pooled $\mathrm{AUC}$ inf from the intravenous profile. All parameters are presented as geometric means with standard deviations.

\section{Calculation of maximum residue exposure}

To calculate the maximum residue exposure (MRE) we followed the method outlined by the European Medicines Agency (EMA) for establishing withdrawal periods (The European Agency for the Evaluations of Medicinal Products, 1995). Residue depletion in tissues follows a one compartmental model and thereby can be described by one exponential term. The first order kinetic equation for residue concentration at time $t$ is $\mathrm{C}_{0} * \mathrm{e}^{-\lambda t}$, where $\mathrm{C}_{0}$ is the hypothetical concentration at time 0 and $\lambda$ is the elimination rate constant estimated from an ordinary least squares regression as described above. We took the MRE to be the carprofen concentration below which concentrations of $95 \%$ of a population of cow tissues of a particular type would be expected to lie, with $95 \%$ confidence. We based this calculation upon the average $\mathrm{C}_{\mathrm{t}}$. Therefore, MRE values in $\mathrm{mg} / \mathrm{kg}$ were calculated as $\mathrm{M}_{i}+\mathrm{SD}_{i} * 5.144$, where $\mathrm{M}_{i}$ and $\mathrm{SD}_{i}$ were the mean concentration and its standard deviation in tissue type $i$. The multiplier 5.144 is the value for a sample size of four cattle and was taken from the table of factors of Hahn and Meeker (2011). Oral exposure in mg for vultures in Phase 3 and Phase 4 of the toxicity study were calculated as (MREkidney*1.00)/4.50, where MREkidney was the maximum residue exposure for kidney tissue, 1.00 was a rough estimate of the amount of edible tissue in kilograms that a vulture would consume in a large meal (see Swan et al. 2006) and 4.5 was a rough estimate of the mean body weight in kilograms of a white-rumped vulture G. bengalensis (the smallest Gyps species). Since, the species of Gyps vulture used in 
this study were larger than $4.5 \mathrm{~kg}$, they received a greater exposure to carprofen than that calculated using MREkidney (see Results). We used the MRE calculated for kidney tissue as this gave the greatest MRE value apart from that given by the muscle at the injection site (see Table 1). We did not use the MRE calculated for the muscle at the injection site as this gave a value that was extremely high and one that would most certainly kill vultures (see Table 1); therefore, we opted to test the average concentration in the muscle at the injection site.

\section{Clinical pathology}

Serum samples were analysed by the Veterinary Clinical Pathology Laboratory of the University of Pretoria using the Cobas Integra 400 (Roche Diagnostics) for activities of alanine transferase (ALT) and alkaline phosphatase (ALP); and concentrations of potassium $(\mathrm{K})$, sodium (Na) and uric acid (UA). Due to limited sample volume, some samples $(n=4)$ for clinical pathology parameters were evaluated by a second commercial accredited laboratory in the United Kingdom (using plasma samples remaining following carprofen residue analysis). Changes in the measured clinical pathology parameters were considered significant if the changes at a particular time were either different to a control group of vultures or were different to the baseline value for a given individual vulture.

\section{Results}

Pharmacokinetic study of carprofen in cattle

The pharmacokinetic profiles (Supplementary Figure 1) and parameters (Supplementary Table 1) were fairly consistent among the six cattle treated at $1.4 \mathrm{mg} / \mathrm{kg}$, with the exception of $\mathrm{T}_{\max }$ and $\mathrm{C}_{\max }$, both of which showed considerable variability. Because of this variability, 
we used the mode, not the mean $\mathrm{T}_{\max }$ as the time at which cattle were to be slaughtered in the tissue residue study.

\section{Pharmacokinetics of carprofen in Gyps vultures}

For this study vulture in pairs were treated with carprofen at $5 \mathrm{mg} / \mathrm{kg}$ by the oral, intramuscular or intravenous route. The pharmacokinetic parameters obtained are presented in Table 1. Carprofen was well tolerated in all exposed vultures. The intravenous and intramuscular profiles were very similar, as a result of very rapid absorption from muscle tissue. The oral profile differed from these profiles in respect to absorption, with half as much carprofen being absorbed, but not in respect to elimination which was of a similar rate despite lower absorption. Although the profiles were not from the same birds, the population absolute bioavailability was roughly estimated at $100 \%$ for the intramuscular route and $42 \%$ for the oral route.

Tissue residue study of carprofen $(2.8 \mathrm{mg} / \mathrm{kg}$ bw ) in cattle

The concentrations of caprofen present in the liver, fat (omental), kidney, muscle (quadriceps), and muscle at injection site were $5.75 \pm 1.49,3.74 \pm 2.50,7.72 \pm 2.38,6.03 \pm 1.59$ and $289.05 \pm 286.05 \mathrm{mg} / \mathrm{kg}$ respectively (Supplementary Table 2, for individual animal data and variation of concentrations between animals). Mean carprofen concentration at the injection site was 37 times greater than the next highest mean concentration found in the kidneys and 48 times greater than the mean concentration found in the hind leg muscle. As a result of the extremely high concentration at the injection site, we used both the MRE calculated for kidney and the mean injection site concentration in the toxicity study. 


\section{Toxicity study of carprofen in Gyps vultures}

In general, the four vultures per group were reluctant to eat kidney or muscle tissue provided in Phase 1 and Phase 2, respectively. As this was the case for both carprofen-rich and carprofen-free tissues, this was likely to be because individual housing of vultures prevented competitive feeding cues and caused a certain level of stress. The result was rather low dose levels across the two phases ( 0.12 to $0.90 \mathrm{mg} / \mathrm{kg}$ bw; Supplementary Table 3 ). The highest exposures for Phase 1 (kidney tissue) and Phase 2 (muscle tissue) were 0.87 and $0.90 \mathrm{mg} / \mathrm{kg}$ bw, respectively. No observable or clinical signs of toxicity were evident in any of the treated animals.

Four vultures in Phase 3 and two vultures in Phase 4 were given an oral dose of carprofen at $4.4 \mathrm{mg} / \mathrm{kg} \mathrm{bw}$, which equated to a range of exposures between 23.10 and 37.62 mg (Supplementary table 4). No observable or clinical signs of toxicity were evident in any of these treated animals from phase 3 at $4.4 . \mathrm{mg} / \mathrm{kg}$. Carprofen was characterized by a mean Thalf of $10.29 \pm 5.03 \mathrm{~h}$ (Table 2). All the pharmacokinetic parameters showed substantial variability $(\mathrm{CV}>30 \%$; Table 4$)$. AUClast was more variable than $\mathrm{C}_{\max }$ and $\mathrm{T}_{\max }$, which indicated that both absorption and elimination profiles among vultures differed substantially (Supplementary Figure 2). The estimated fraction of absorption also ranged widely (25 to $103 \%$ ), which is an indicator of pre-systemic elimination, which in turn is indicative of substantial inter-subject variation in metabolic capacity.

Two vultures in Phase 4 were given an oral dose of carprofen at $64.0 \mathrm{mg} / \mathrm{kg}$ bw, which equated to the average carprofen concentration at the injection site of cattle in the tissue residue study $(289.05 \mathrm{mg} / \mathrm{kg}$ ) and exposures of 345.60 and $387.20 \mathrm{mg}$ (Supplementary Table 4). The vulture exposed to the greater amount of carprofen $(387.20 \mathrm{mg})$ showed severe signs of depression (i.e., head drooping, reluctance to move, poor response to external 
stimuli) approximate $48 \mathrm{~h}$ post-exposure. This vulture succumbed to toxicity at $52 \mathrm{~h}$ postexposure. The vulture exposed to the lesser amount of carprofen showed no observable signs of toxicity. On clinical pathology, this vulture showed a moderate increase in ALP compared to the range for non-treatment vultures; whereas, the vulture that died showed a large increase in uric acid concentrations compared to the range for non-treatment vultures (Figure 1)(The calculated healthy values are applicable to the study population are presented in Supplementary Table 5). The uric acid concentrations in the vulture that died represented a 27-fold increase over the pre-treatment concentrations; and more than a 7-fold increase over the non-treatment maximum concentration (Figure 1). Similarly, ALT concentration in the vulture that died was above the range for non-treatment vultures from $24 \mathrm{~h}$ onwards and showed a marked increase at $48 \mathrm{~h}$. In terms of pre-treatment concentration, the change in ALT represented a 2.5- and 15- fold increase at 24 and 48 hours. Finally, potassium (but not sodium) concentration in the vulture that died showed a moderate increase at $48 \mathrm{~h}$ postexposure (Figure 1).

For a terminal blood sample revealed extremely high uric acid (15.20 mMol/L), ALT (813.00 U/L) and potassium (10.10 mMol/L) levels in the bird that died. On necropsy, the most significant findings were in the kidneys, liver, spleen and lungs. The kidneys revealed widespread dilatation of tubules with loss of the cuboidal lining cells and their replacement with an amorphous pink material in which pyknotic cell debris was entrapped (Figure 2). Radiating aggregates of purple crystalline spicules were also present in many of these tubules. Less affected tubules showed increased eosinophilia of the cytoplasm of the lining cells, varying degrees of shrinking and basophilia of the nuclei and even desquamation of the cells themselves from the basement membrane. Many of these tubules also contained varying amounts of crystalline urates. A small number of heterophils were present at the periphery of 
some of the damaged tubules. Globular urates were also present in the lumens of some of the tubules. The liver and spleen had large multifocal areas of necrosis associated with uric acid crystal formation, and also associated with a small number of inflammatory cells, mainly heterophils; while the lungs had very small foci scattered within the parenchyma involving only a few cells.

Comparing the toxicokinetic parameters of the two vultures dosed at $64.0 \mathrm{mg} / \mathrm{kg}, \mathrm{C}_{\max }$ was $17 \%$ greater in the individual that survived than the individual that died; but $\mathrm{AUC}_{\text {last }}$ and Thalf were 89 and $332 \%$ greater, respectively, in the individual that died than the individual that survived (Table 3). The bird that died was the adult. The extremely long Thalf in the vulture that died was important, as was the prolonged period during which carprofen concentrations in its plasma remained around $30 \mu \mathrm{g} / \mathrm{mL}$ (i.e., for more than $20 \mathrm{~h}$ ) before declining at a very slow rate (Figure 3). This profile indicates zero-order metabolism. Again, as for the pharmacokinetic studies all evaluated parameters showed substantial variability $\left(\mathrm{CV}>30 \%\right.$ ) with $\mathrm{AUCl}_{\text {last }}$ being more variable than $\mathrm{C}_{\max }$ and $\mathrm{T}_{\max }$ (Table 3 ).

While not planned, an interesting additional result was observed for vultures G31917 and G30796. G31917 was treated orally at $4.4 \mathrm{mg} / \mathrm{kg}$ bw in the toxicity study and intramuscularly at $5 \mathrm{mg} / \mathrm{kg}$ bw in the pharmacokinetics study, with a resultant $\mathrm{AUC}_{\text {last }}$ of 170.82 and $579.63 \mu \mathrm{g} / \mathrm{mL}^{*} \mathrm{~h}$, respectively. G30796 was treated orally at $64.0 \mathrm{mg} / \mathrm{kg}$ bw orally (and survived) and intramuscularly at $5 \mathrm{mg} / \mathrm{kg}$, with a resultant AUClast of 650.16 and $690.79 \mu \mathrm{g} / \mathrm{mL}^{*} \mathrm{~h}$, respectively. These findings yielded relative bioavailabilities of approximately $28 \%$ and $8 \%$ for G31917 and G30796, respectively, for dose normalised parameters; and indicated a substantial first pass effect present in both vultures (Figure 4).

\section{Discussion}


Carprofen is a non-steroidal anti-inflammatory drug from the carboxylic acid group (Riviere and Papich, 2013). Like other NSAIDs, carprofen is believed to function via the inhibition of cyclooxygenase (COX) enzyme systems. The drug is widely used globally as a veterinary medicine for the modulation of pain and inflammation in pets, horses and production animals. In South Africa, carprofen is mainly used under intensive farming conditions as adjunct therapy for the control of acute inflammation associated with respiratory disease (Carrington et al., 2013). Carprofen is also recommended as a drug of choice for the management of pain and inflammation in raptors and other birds, as an off-label indication (Carpenter, 2005).

For this study, we set out to ascertain the safety of carprofen in a susceptible vulture species using the same parameters from previous vulture toxicity studies. The study model used, assumes a worst case scenario of the double dosing of cattle recently prior to its death, and a vulture being exposed to the highest concentration in a particular tissue in a said meat as a kilogram meal. For this study we were able to demonstrate that carprofen is generally harmless to Gyps vultures at concentrations present in most contaminated animal tissues. However, this was not the case when considering the high concentrations present at injection sites. If a vulture were to consume muscle tissue from the injection site from a cow treated with carprofen just prior to its death, then it could ingest a very high concentration of the drug and could die as a result. The reason for the high concentration of carprofen at the injection site appears to be slow absorption of the drug. Yet, only two of the four cattle dosed with carprofen showed very high concentrations at the injection site. Further, only one of the two Gyps vultures exposed to concentrations based on injection site results died. The reason for this is probably individual variation in tolerance and zero-order elimination, as is the case for Gyps vultures exposed to diclofenac and ketoprofen (see below) (Naidoo et al., 2009, Naidoo et al., 2010a). Individual variation among cattle in terms of carprofen absorption rate and 
among Gyps vultures in terms of carprofen toxicity, make it difficult to determine what impact carprofen contamination of cattle carcasses (left to scavengers) would have on Gyps vulture populations. Nevertheless, our data suggest that a single Gyps vultures feeding on a cattle carcass rich in carprofen residues could die if they consume the entire area of drug depot.

\section{Implications for Gyps vulture conservation}

Two cattle in the tissue residue study had concentrations of carprofen at the injection site of $>511.00 \mathrm{mg} / \mathrm{kg}$, but the other two cattle had concentrations of carprofen at the injection site of $<55.00 \mathrm{mg} / \mathrm{kg}$ (almost a ten-fold difference). High inter-animal variability was seen in all tissue types ( $\mathrm{CV}>25 \%)$, but was greatest at the injection site (99\%). This phenomenon was unlikely solely due to sampling error, since carprofen concentrations in replicate samples from each individual cow were similar (average intra-animal \%CV was $48 \%$ and higher than for all other tissues). Given that the proportion of edible tissue on a typical carcass that may contain lethal levels would be expected to be very small (i.e., solely that which immediately surrounds the injection site), the risk associated with the use of carprofen in cattle would be smaller than that for diclofenac and ketoprofen.

Nonetheless the potential does exist that at a single feeding, a single Gyps vulture could consume the entire carprofen-rich injection site tissue and succumb from toxicity. While the method we've selected is highly conservative in estimating exposure and safety based on an unlikely exposure to $1 \mathrm{~kg}$ of carprofen rich tissue, the relative exposure can be further evaluated in terms of the MRE. According to the prescribed EMA method, the safety of the drug at the injection site is further considered in terms of potential exposure to $300 \mathrm{~g}$ of tissue rich in said residue. If the latter method is taken consideration, in conjunction with the 
high concentration of $559 \mathrm{mg} / \mathrm{kg}$ found in the one cow, a bird would have been exposed to dose of $167 \mathrm{mg} / \mathrm{kg}$. If the said bird was at the lower end of the weight range for the whitebacked vultures, a bird of $3.5 \mathrm{~kg}$ would be exposed to $47.7 \mathrm{mg} / \mathrm{kg}$, which is not substantially lower than the test dose of $64 \mathrm{mg} / \mathrm{kg}$, which shows the model used while being conservation is not inaccurate.

In South Asia carprofen is marketed for use in dogs only, where the recommended dose $(2-4 \mathrm{mg} / \mathrm{kg})$ is within the range that Gyps vultures can tolerate. However, the misuse of diclofenac intended for human use in livestock is rampant in South Asia; and therefore, the misuse of carprofen in livestock is possible. That said, a series of surveys of domesticated ungulate carcasses left for scavengers across India (the largest country and user of NSAIDs in South Asia), between 2004 and 2010, have not (to date) encountered any detectable carprofen contamination (Taggart et al., 2007, Taggart et al., 2009, Cuthbert et al., 2011). The combination of the particular lethality of carprofen and its apparently negligible use in livestock in South Asia suggests that it is unlikely to present a significant threat to Gyps vultures there at the current time. That is not to say that carprofen use might not impede recovery of South Asia's critically endangered Gyps vultures if regional governments do not control its use appropriately.

A further consideration is the availability of carprofen in cattle injectable formulations in South Africa and other countries where other species of threatened vultures are found. We would strongly recommend that carprofen be restricted for use in the intensive farming sector, where incidence of respiratory (and other) disease are more likely to occur and carcasses are disposed of by means other than provision to vultures at feeding sites (i.e., incineration and burial). Furthermore, while it would be tempting to remove injection site 
tissue from cattle carcasses before provision at feeding stations, this relies on knowing exactly how many doses of the drug the animal had been given prior to death and exactly where on the animal these doses had been administered. Lastly, the use of carprofen in cattle kept under extensive farming conditions should be precautionary stopped. Further consideration can perhaps also be given to the development of oral formulations of carprofen for use in cattle in these areas.

\section{Insights into NSAID toxicity in Gyps vultures}

The vulture that died in this study was exposed to $387.20 \mathrm{mg}$ of carprofen, while another vulture that survived was exposed to $345.60 \mathrm{mg}$ of carprofen. Substantial differences in individual intolerance of NSAIDs were also seen for both diclofenac (Oaks et al. 2004) and ketoprofen (Naidoo et al. 2010). Carprofen toxicity in Gyps vultures also resembles that of diclofenac and ketoprofen in respect to toxicokinetics, specifically: zero-order elimination; and the subsequent extended elimination profile. The vulture that died from a high dose of carprofen clearly showed zero-order elimination - that is, a constant amount of drug eliminated per unit time (see linear elimination in Figure 5); whereas, the vulture that survived from a high dose of carprofen clearly shows first-order elimination - that is, a constant proportion of drug eliminated per unit time (see exponential elimination in Figure 5). Zero-order elimination suggests limited enzyme capacity for processing a given drug, which results in the accumulation of that drug in the body and thereby toxicity. The effect of zeroorder elimination was also associated with elimination and not absorption, as the vulture that died from a high dose of carprofen showed greater values for AUC, Thalf and MRT than the vulture that survived from a high dose of carprofen; but $\mathrm{C}_{\max }$ and $\mathrm{T}_{\max }$ was similar between the two vultures. Further, AUC, Thalf $_{\text {and }}$ MRT for the vulture that survived were within the 
range of values for those parameters among the vultures given a small dose of carprofen (i.e., $4.4 \mathrm{mg} / \mathrm{kg}$ ). While still speculative, we believe that the point of capacity limitation lies with the hepatic cytochrome P450 (CYP) enzymes concentrations and or ratios. Also with the bird dying being an adult, this would indicate that the constraints present in metabolism is not due age-specific limitations in metabolism, but rather individual limitations in metabolic capacity.

In this study, toxicity was monitored through clinical, clinical pathology, toxicokinetics and necropsy following previous toxicity studies in vultures (Oaks et al., 2004, Swan et al., 2006, Naidoo et al., 2010b). The vulture that died showed general depression and a reluctance to respond to stimuli. Clinical pathology showed clear progression of disease: plasma uric acid concentration exceeding the normal range at $24 \mathrm{~h}$, indicative of kidney damage; and plasma ALT concentration also exceeding the normal range at $48 \mathrm{~h}$, indicative of substantial damage to other tissues. Death probably resulted from the increase in plasma potassium concentration and cardiac toxicity, which has been shown to be compensatory to an increase in plasma uric acid concentration (Lumeij, 1994). This progression of disease is very similar to that seen in vultures exposed to diclofenac (Oaks et al., 2004) and ketoprofen (Naidoo et al., 2010b), suggesting that all three drugs have the same mechanism of toxicity. While the mechanism of toxicity still remains elusive, cascading kidney toxicity is either secondary to hypoperfusion (Meteyer et al., 2005) or results from alteration in the renal ability to excrete uric acid (Naidoo and Swan, 2009).

\section{Innovations for NSAID safety testing in Gyps vultures}

The method followed here builds on the methods used in previous NSAID toxicity tests in Gyps vultures. It incorporates studies in cattle to determine a more accurate measure of the maximum exposure to vultures through the examination of the pharmacokinetic profile in 
cattle. Previous toxicity studies on diclofenac, meloxicam and ketoprofen relied on data from residue depletion studies published by the European Medicines Agency to estimate when cattle are likely to have reached their maximum residue concentrations in tissues and what tissue types have the highest maximum concentration at those times. Residue depletion studies are not necessarily accurate at determining such parameters because cattle are slaughtered at predetermined times and often large time intervals are used that may not correspond to true maxima. Analysing a time series of plasma samples for $\mathrm{C}_{\max }$ and $\mathrm{T}_{\max }$ is a more accurate alternative because repeated measurements can be made on the same individual. Importantly, observed drug concentrations in plasma are proportional to those expected in tissues. Accurate $\mathrm{C}_{\max }$ and $\mathrm{T}_{\max }$ lead to accurate maximum tissue residue levels, which in turn lead to an accurate measure of maximum exposure.

Note that published pharmacokinetics studies in cattle on the given drug should be used with caution as these may use animals or methods of administration not entirely appropriate for a toxicity test in Gyps vultures. This was the case for carprofen where two studies had previously examined carprofen pharmacokinetics in calves (3-4 months of age) using intravenous injection and showed considerably different parameters to those we found here (Delatour et al., 1996, Brentnall et al., 2013). It may be that there are important age related differences in carprofen pharmacokinetics in cattle. This is important because cattle carcasses contaminated with NSAIDs and left for vultures in South Asia (and probably South Africa) are far less likely to be those of calves (Taggart et al., 2007).

MRE, developed by the EMA, was used as the worst case scenario exposure for vultures. The philosophy of the method is based on chemical safety principles that protect people from potentially dangerous residues in their food. The use of the upper tolerance value takes into account the worst case exposure resulting from linear tissue depletion by 
converting tissue residue results from the test population (of small sample size) into a value that would cater for the potentially large inter-subject differences in the various cattle breeds available. As a result, our estimate of exposure for the non-injection site scenario best reflects the true worst case exposure for wild vultures, if cattle are treated at doubled the dose recommended. Further caution will need to apply if higher doses or more frequent administrations occur. The method adopted for this study was also stricter than that previously applied in the testing of meloxicam and ketoprofen, as both those studies simply doubled the potential tissue residue concentrations. In this study, double the tissue residue concentration in all tissue types was lower than the MRE (e.g. $\sim 15 \mathrm{mg} / \mathrm{kg}$ vs. $20 \mathrm{mg} / \mathrm{kg}$ for the kidneys).

Finally, this method examined the concentration of the tested drug at the injection site. The injection site has also been considered as an area of potential concern in human food safety, as it is known that drugs may persist at elevated levels at such sites. The importance of this is best emphasised by the EMA's own guidelines, that suggest that the injection site residue concentration should be substituted for the wider muscle concentration (when higher) to also take into account the worst case scenario of a person accidentally being exposed to meat sourced from the injection site. While we expected (in general) a difference in injection site and muscle tissue concentrations, since termination was at plasma $T_{\max }$, the substantial difference observed here was certainly not expected. In addition, such a difference was contrary to findings in toxicity studies for meloxicam and diclofenac, where the concentrations at the injection site was lower than that in muscle away from the injection site (EMA public safety information; The European Agency for the Evaluation of Medicinal Products, 2003 and The European Agency for the Evaluation of Medicinal Products, 1999). Our findings thus highlight the potential danger of injection site tissue from animals treated 
with NSAIDs, especially if more than one dose has been administered at the same site.

\section{Acknowledgements}

We like to thank the staff of the University Pretoria Biomedical Research Centre and the staff and volunteers of the VulPro for making this study possible. The study was funded partly by the Royal Society for the Protection of Birds and the Chester Zoo.

\section{References}

1. Arnold KE, Brown AR, Ankley GT, Sumpter JP (2014) Medicating the environment: assessing risks of pharmaceuticals to wildlife and ecosystems. Philos Trans R Soc Lond B Biol Sci 369: 20130569.

2. Brentnall C, Cheng Z, McKellar Q, Lees P (2013) Influence of oxytetracycline on carprofen pharmacodynamics and pharmacokinetics in calves. J Vet Pharmacol Ther 36: $320-328$.

3. Carpenter J (2005) Exotic Animal Formulary Avian and Exotic Pets (ed 3). St. Louis, MO, Saunders.

4. Carrington C, du Plessis A, Naidoo V (2013) IVS Desk Reference, MIMS, Saxonworld

5. Cuthbert RJ, Dave R, Chakraborty SS, Kumar S, Prakash S, Ranade SP, Prakash V (2011) Assessing the ongoing threat from veterinary non-steroidal anti-inflammatory drugs to Critically Endangered Gyps vultures in India. Oryx 45: 420-426.

6. Delatour P, Foot R, Foster A, Baggo D, Lees P (1996) Pharmacodynamics and chiralpharmacokinetics of carprofen in calves. Br Vet J 152: 183-198.

7. Fourie T, Cromarty D, Duncan N, Wolter K, Naidoo V (2015) The Safety and Pharmacokinetics of Carprofen, Flunixin and Phenylbutazone in the Cape Vulture (Gyps coprotheres) following Oral Exposure. PloS One 10: e0141419.

8. Green RE, Newton I, Shultz S, Cunningham AA, Gilbert M, Pain DJ, Prakash V (2004) Diclofenac poisoning as a cause of vulture population declines across the Indian subcontinent. J Appl Ecol 41: 793-800.

9. Green RE, Taggart MA, Senacha KR, Raghavan B, Pain DJ, Jhala Y, Cuthbert R (2007) Rate of decline of the oriental white-backed vulture population in India estimated from a survey of diclofenac residues in carcasses of ungulates. PLoS One 2: 
e686.

10. Hahn GJ, Meeker WQ (2011) Statistical Intervals: A Guide for Practitioners. John Wiley \& Sons, United States.

11. Kuster A, Adler N (2014) Pharmaceuticals in the environment: scientific evidence of risks and its regulation. Philos Trans R Soc Lond B Biol Sci 369: 20130587.

12. Lumeij JT (1994) Nephrology. Avian medicine, principles and application. Lake Worth, USA: Wingers Publishing Inc, pp.538-555.

13. Margalida A, Bogliani G, Bowden CG, Donazar JA, Genero F, Gilbert M, Karesh WB, Kock R, Lubroth J, Manteca X, Naidoo V, Neimanis A, Sanchez-Zapata JA, Taggart MA, Vaarten J, Yon L, Kuiken T, Green RE (2014) Science and regulation. One Health approach to use of veterinary pharmaceuticals. Science 346: 1296-1298.

14. Meteyer CU, Rideout BA, Gilbert M, Shivaprasad H, Oaks JL (2005) Pathology and proposed pathophysiology of diclofenac poisoning in free-living and experimentally exposed oriental white-backed vultures (Gyps bengalensis). J Wildl Dis 41: 707-716.

15. Naidoo V, Wolter K, Cuthbert R, Duncan N (2009) Veterinary diclofenac threatens Africa's endangered vulture species. Regul Toxicol Pharm 53: 205-208.

16. Naidoo V, Swan GE (2009) Diclofenac toxicity in Gyps vulture is associated with decreased uric acid excretion and not renal portal vasoconstriction. Comp Biochem Phys C 149: 269-274.

17. Naidoo V, Venter L, Wolter K, Taggart M, Cuthbert R (2010a) The toxicokinetics of ketoprofen in Gyps coprotheres: toxicity due to zero-order metabolism. Arch Toxicol 84: 761-766.

18. NaidooV, Wolter K, Cromarty D, Diekmann M, Duncan N, Meharg AA, Taggart MA, Venter L, Cuthbert R (2010b) Toxicity of non-steroidal anti-inflammatory drugs to Gyps vultures: a new threat from ketoprofen. Biol Lett 6: 339-341.

19. Oaks JL, Gilbert M, Virani MZ, Watson RT, Meteyer CU, Rideout BA, Shivaprasad H, Ahmed S, Chaudhry MJI, Arshad M (2004) Diclofenac residues as the cause of vulture population decline in Pakistan. Nature 427: 630-633.

20. Prakash V, Green R, Pain D, Ranade S, Saravanan S, Prakash N, Venkitachalam R, Cuthbert R, Rahmani A, Cunningham A (2007) Recent changes in populations of resident Gyps vultures in India. J Bombay Nat Hist Soc 104: 129-135.

21. Richman L, Hayward G (2011). Fowler's zoo and wild animal medicine: current therapy. Elsevier Sanders, Missouri.

22. Riviere JE, Papich MG (2013) Veterinary Pharmacology and Therapeutics. John Wiley \& Sons, United States.

23. Schwaiger J, Ferling H, Mallow U, Wintermayr H, Negele R (2004) Toxic effects of 
the non-steroidal anti-inflammatory drug diclofenac: Part I: histopathological alterations and bioaccumulation in rainbow trout. Aquat Toxicol 68: 141-150.

24. Swan G, Naidoo V, Cuthbert R, Green RE, Pain DJ, Swarup D, Prakash V, Taggart M, Bekker L, Das D (2006a) Removing the threat of diclofenac to critically endangered Asian vultures. PLoS biology 4: e66.

25. Swan GE, Cuthbert R, Quevedo M, Green RE, Pain DJ, Bartels P, Cunningham AA, Duncan N, Meharg AA, Oaks JL, Parry-Jones J (2006b). Toxicity of diclofenac to Gyps vultures. Biol lett 2: 279-282.

26. Swarup D, Patra R, Prakash V, Cuthbert R, Das D, Avari P, Pain D, Green R, Sharma A, Saini M (2007) Safety of meloxicam to critically endangered Gyps vultures and other scavenging birds in India. Anim Conserv 10: 192-198.

27. Taggart M, Senacha K, Green R, Jhala Y, Raghavan B, Rahmani A, Cuthbert R, Pain D, Meharg A (2007) Diclofenac residues in carcasses of domestic ungulates available to vultures in India. Environ Int 33: 759-765.

28. Taggart MA, Senacha KR, Green RE, Cuthbert R, Jhala YV, Meharg AA, Mateo R, Pain DJ (2009) Analysis of nine NSAIDs in ungulate tissues available to critically endangered vultures in India. Environ Sci Technol 43: 4561-4566.

29. The European Agency for the Evaluation of Medicinal Products, 2003. Diclofenac Summary Report. EMEA/MRL/885/03-Final.

30. The European Agency for the Evaluation of Medicinal Products, 1999. Meloxicam Summary Report 2. EMEA/MRL/571/99-Final.

31. The European Agency for the Evaluations of Medicinal Products, 1995. Approach towards harmonisation of withdrawal periods. EMEA/CVMP/036/95, 1-37. 
Table 1: Pharmacokinetic parameters obtained using non-compartmental modelling for six adult $G$. africanus treated with carprofen at $5 \mathrm{mg} / \mathrm{kg}$ body weight via intravenous injection (n $=2)$, intramuscular injection $(n=2)$ and oral gavage $(n=2)$. Each vulture has a unique code. Also shown are the geometric mean and standard deviation (SD).

Table 2: Pharmacokinetic parameters obtained using non-compartmental modelling for six adult Gyps vultures (G. africanus) treated with carprofen at $4.4 \mathrm{mg} / \mathrm{kg}$ via an oral gavage in Phase 3 and Phase 4 of a toxicity study.

Table 3: Toxicokinetic parameters obtained using non-compartmental modelling for two adult Gyps vultures $(G$.) treated with carprofen at $64 \mathrm{mg} / \mathrm{kg}$ via an oral gavage in Phase 4 of a toxicity study. Note: G31961 died.

Supplementary Table 1: Pharmacokinetics parameters obtained using non-compartmental modelling for four mixed-breed female Bos taurus cattle (15-18 moa) treated with carprofen (Norocarp) at $1.4 \mathrm{mg} / \mathrm{kg}$ body weight. Also shown are the geometric mean, standard deviation $(\mathrm{SD})$ and coefficient of variation $(\mathrm{CV})$ as a percentage.

Supplementary Table 2: Mean tissue concentrations $(\mathrm{mg} / \mathrm{kg})$ of carprofen from three samples from four female Friesian Bos taurus cattle (9 months of age) treated with Norocarp at 2.8 $\mathrm{mg} / \mathrm{kg}$ body weight. Also shown are the arithmetic means and standard deviations (SD) of the animal means and maximum residue exposure (MRE).

Supplementary Table 3: Carprofen dose and exposure to Gyps vultures in Phase 1 (kidney) and Phase 2 (muscle) of the toxicity study. Also shown are individual codes, vulture body weights, amount of tissue consumed and concentration of carprofen used to calculate dose and exposure.

Supplementary Table 4: Carprofen dose and exposure to Gyps vultures in Phase 3 (dose = $4.4 \mathrm{mg} / \mathrm{kg})$ and Phase $4(64 \mathrm{mg} / \mathrm{kg})$ of the toxicity study. Also shown are individual codes and vulture body weights. 
Supplementary Table 5: Descriptive statistics for biochemical parameters from samples of Gyps vulture plasma collected in the absence and presence of carprofen. Parameters in the absence of carprofen were obtained from the control groups and samples evaluated prior to treatment from the descriptive pharmacokinetic phase of the study. 
Table 1: Pharmacokinetic parameters obtained using non-compartmental modelling for six adult G. africanus treated with carprofen at $5 \mathrm{mg} / \mathrm{kg}$ body weight via intravenous injection $(\mathrm{n}=2)$, intramuscular injection $(\mathrm{n}=2)$ and oral gavage $(\mathrm{n}=2)$. Each vulture has a unique code. Also shown are the geometric mean and standard deviation (SD).

\begin{tabular}{|c|c|c|c|c|c|c|c|c|c|c|c|c|c|}
\hline \multirow{2}{*}{ Parameter } & \multirow{2}{*}{ Unit } & \multicolumn{4}{|c|}{ Intravenous } & \multicolumn{4}{|c|}{ Intramuscular } & \multicolumn{4}{|c|}{ Oral } \\
\hline & & G31980 & G31943 & G.Mean & SD & G31917 & G30796 & G.Mean & SD & G32857 & G31997 & G.Mean & SD \\
\hline $\mathrm{C}_{\max }$ & $\mu \mathrm{g} / \mathrm{mL}$ & 27.79 & 38.09 & 32.54 & 7.28 & 30.76 & 34.34 & 32.50 & 2.53 & 14.65 & 17.53 & 16.03 & 2.04 \\
\hline $\mathrm{T}_{\max }$ & $\mathrm{h}$ & 1.00 & 1.00 & 1.00 & 0.00 & 3.00 & 2.00 & 2.45 & 0.71 & 1.00 & 1.00 & 1.00 & 0.00 \\
\hline $\mathrm{AUC}_{\text {last }}$ & $\mu \mathrm{g} / \mathrm{mL}^{*} \mathrm{~h}$ & 658.43 & 543.84 & 598.39 & 81.03 & 690.98 & 579.63 & 632.86 & 78.73 & 153.53 & 344.94 & 230.12 & 135.35 \\
\hline $\mathrm{AUC}_{\mathrm{inf}}$ & $\mu \mathrm{g} / \mathrm{mL}^{*} \mathrm{~h}$ & 133.31 & 24.61 & 57.28 & 76.86 & 40.89 & 15.51 & 25.18 & 17.95 & 3.09 & 48.32 & 12.23 & 31.98 \\
\hline$\lambda$ & $\mathrm{h}^{-1}$ & 0.04 & 0.07 & 0.05 & 0.02 & 0.07 & 0.08 & 0.08 & 0.01 & 0.09 & 0.04 & 0.06 & 0.03 \\
\hline $\mathrm{AUMC}_{\text {last }}$ & $\mu \mathrm{g} / \mathrm{mL}^{*} \mathrm{~h}^{2}$ & 11256.70 & 7271.06 & 9047.00 & 2818.27 & 10918.40 & 8027.24 & 9361.87 & 2044.36 & 1867.96 & 6133.33 & 3384.79 & 3016.07 \\
\hline $\mathrm{T}_{\text {half }}$ & $\mathrm{h}$ & 18.51 & 10.58 & 13.99 & 5.61 & 10.43 & 8.17 & 9.23 & 1.60 & 7.92 & 16.00 & 11.25 & 5.71 \\
\hline MRT & $\mathrm{h}$ & 26.80 & 15.53 & 20.40 & 7.97 & 18.44 & 15.05 & 16.66 & 2.40 & 13.10 & 24.33 & 17.85 & 7.94 \\
\hline $\mathrm{Cl} / \mathrm{F}^{*}$ & $\mathrm{~L} / \mathrm{h} * \mathrm{~kg}$ & 0.01 & 0.01 & 0.01 & 0.00 & 0.01 & 0.01 & 0.01 & 0.00 & 0.03 & 0.01 & 0.02 & 0.01 \\
\hline $\mathrm{V}_{\mathrm{z}} / \mathrm{F}^{*}$ & $\mathrm{~L} / \mathrm{kg}$ & 0.17 & 0.13 & 0.15 & 0.02 & 0.10 & 0.10 & 0.10 & 0.00 & 0.36 & 0.29 & 0.33 & 0.05 \\
\hline $\mathrm{V}_{\mathrm{ss}} / \mathrm{F}^{*}$ & $\mathrm{~L} / \mathrm{kg}$ & 0.17 & 0.14 & 0.15 & 0.02 & 0.13 & 0.13 & 0.13 & 0.00 & 0.42 & 0.31 & 0.36 & 0.08 \\
\hline $\mathrm{F}$ & $\%$ & - & - & - & - & 114.95 & 96.42 & 105.28 & 13.10 & 25.54 & 57.38 & 38.28 & 22.52 \\
\hline
\end{tabular}

*For intravenous injection these are $\mathrm{Cl}, \mathrm{Vz}$ and Vss (see Methods) 
Table 2: Pharmacokinetic parameters obtained using non-compartmental modelling for six adult Gyps vultures (G. africanus) treated with carprofen at $4.4 \mathrm{mg} / \mathrm{kg}$ via an oral gavage in Phase 3 and Phase 4 of a toxicity study.

\begin{tabular}{|c|c|c|c|c|c|c|c|c|c|c|}
\hline \multirow{2}{*}{ Parameter } & \multirow{2}{*}{ Units } & \multicolumn{6}{|c|}{ Vulture } & \multirow{2}{*}{$\begin{array}{c}\text { Geometric } \\
\text { Mean }\end{array}$} & \multirow{2}{*}{ SD } & \multirow{2}{*}{$\mathrm{CV}(\%)$} \\
\hline & & G19042 & G30404 & G31917 & G31977 & G30402 & G30258 & & & \\
\hline$\overline{\mathrm{C}_{\max }}$ & $\mu \mathrm{g} / \mathrm{mL}$ & 21.06 & 30.28 & 12.76 & 12.39 & 21.82 & 8.91 & 16.42 & 7.95 & 48.43 \\
\hline $\mathrm{T}_{\max }$ & $\mathrm{h}$ & 2 & 2 & 2 & 2 & 2 & 2 & 2.00 & 0.00 & 0.00 \\
\hline AUClast & $\mu \mathrm{g} / \mathrm{mL}^{*} \mathrm{~h}$ & 270.21 & 481.09 & 170.82 & 124.75 & 548.61 & 131.12 & 241.68 & 184.67 & 76.41 \\
\hline $\mathrm{AUC}_{\mathrm{inf}}$ & $\mu \mathrm{g} / \mathrm{mL}^{*} \mathrm{~h}$ & 273.51 & 511.37 & 171.43 & 125.33 & 677.27 & 139.78 & 256.45 & 227.51 & 88.71 \\
\hline$\lambda$ & $\mathrm{h}^{-1}$ & 0.08 & 0.05 & 0.11 & 0.1 & 0.04 & 0.06 & 0.07 & 0.03 & 40.80 \\
\hline $\mathrm{AUMC}_{\text {last }}$ & $\mu \mathrm{g} / \mathrm{mL} / \mathrm{h}^{2}$ & 3317 & 7713 & 2038 & 1360 & 10182 & 1899 & 3333.07 & 3651.14 & 109.54 \\
\hline Thalf & $\mathrm{h}$ & 8.39 & 13.31 & 6.59 & 6.87 & 19.78 & 11.88 & 10.29 & 5.03 & 48.86 \\
\hline MRT & $\mathrm{h}$ & 12.93 & 19.45 & 12.11 & 11.15 & 29.57 & 17.62 & 16.14 & 6.91 & 42.83 \\
\hline $\mathrm{Cl}$ & $\mathrm{L} / \mathrm{h} * \mathrm{~kg}$ & 0.02 & 0.01 & 0.03 & 0.04 & 0.01 & 0.36 & 0.03 & 0.14 & 448.71 \\
\hline $\mathrm{V}_{\mathrm{z}}$ & $\mathrm{L} / \mathrm{kg}$ & 0.22 & 0.17 & 0.25 & 0.35 & 0.19 & 6.13 & 0.40 & 2.41 & 609.02 \\
\hline $\mathrm{V}_{\mathrm{ss}}$ & $\mathrm{L} / \mathrm{kg}$ & 0.24 & 0.17 & 0.31 & 0.39 & 0.19 & 6.3 & 0.43 & 2.47 & 580.32 \\
\hline $\mathrm{F}$ & $\%$ & 51.08 & 90.94 & 32.29 & 23.58 & 103.71 & 24.79 & 45.69 & 34.91 & 76.41 \\
\hline
\end{tabular}


Table 3: Toxicokinetic parameters obtained using non-compartmental modelling for two adult Gyps vultures $(G$.) treated with carprofen at 64 $\mathrm{mg} / \mathrm{kg}$ via an oral gavage in Phase 4 of a toxicity study. Note: G31961 died.

\begin{tabular}{|c|c|c|c|c|c|c|}
\hline \multirow{2}{*}{ Parameter } & \multirow{2}{*}{ Units } & \multicolumn{2}{|c|}{ Vulture } & \multirow{2}{*}{ Mean } & \multirow{2}{*}{ SD } & \multirow{2}{*}{$\mathrm{CV}(\%)$} \\
\hline & & G30796 & G31961 & & & \\
\hline $\mathrm{C}_{\max }$ & $\mu \mathrm{g} / \mathrm{ml}$ & 40.37 & 33.70 & 36.88 & 4.72 & 12.79 \\
\hline $\mathrm{T}_{\max }$ & $\mathrm{h}$ & 2.00 & 2.00 & 2.00 & 0.00 & 0.00 \\
\hline AUClast & $\mu \mathrm{g} / \mathrm{ml}{ }^{*} \mathrm{~h}$ & 650.16 & 1231.27 & 894.72 & 410.91 & 45.93 \\
\hline $\mathrm{AUC}_{\mathrm{inf}}$ & $\mu \mathrm{g} / \mathrm{ml} * \mathrm{~h}$ & 667.34 & 2064.18 & 1173.67 & 987.72 & 84.16 \\
\hline$\lambda$ & $\mathrm{h}^{-1}$ & 0.07 & 0.02 & 0.04 & 0.04 & 94.49 \\
\hline AUMC last & $\mu \mathrm{g} / \mathrm{ml} / \mathrm{h}^{2}$ & 8622.00 & 27113.00 & 15289.48 & 13075.11 & 85.52 \\
\hline$T_{\text {half }}$ & $\mathrm{h}$ & 8.74 & 37.75 & 18.16 & 20.51 & 112.93 \\
\hline MRT & $\mathrm{h}$ & 14.48 & 54.48 & 28.09 & 28.28 & 100.70 \\
\hline $\mathrm{Cl}$ & $\mathrm{L} / \mathrm{h} * \mathrm{~kg}$ & 0.01 & 0.02 & 0.01 & 0.01 & 50.00 \\
\hline $\mathrm{V}_{\mathrm{z}}$ & $\mathrm{L} / \mathrm{kg}$ & 0.08 & 1.32 & 0.32 & 0.88 & 269.82 \\
\hline $\mathrm{V}_{\mathrm{ss}}$ & $\mathrm{L} / \mathrm{kg}$ & 0.10 & 1.32 & 0.36 & 0.86 & 237.44 \\
\hline $\mathrm{F}$ & $\%$ & 91.02 & 209.80 & 138.19 & 83.99 & 60.78 \\
\hline
\end{tabular}

F: For the calculation of the fraction of absorption, plasma concentrations were normalised to $1 \mathrm{mg} / \mathrm{kg}$ exposure for the birds dosed orally. 
Supplementary Table 1: Pharmacokinetics parameters obtained using non-compartmental modelling for four mixed-breed female Bos taurus cattle (15-18 moa) treated with carprofen (Norocarp) at $1.4 \mathrm{mg} / \mathrm{kg}$ body weight. Also shown are the geometric mean, standard deviation (SD) and coefficient of variation $(\mathrm{CV})$ as a percentage.

\begin{tabular}{|c|c|c|c|c|c|c|c|c|}
\hline \multirow{2}{*}{ Parameter } & \multirow{2}{*}{ Unit } & \multicolumn{4}{|c|}{ Cow Code } & \multirow{2}{*}{$\begin{array}{c}\text { Geometric } \\
\text { mean }\end{array}$} & \multirow{2}{*}{ SD } & \multirow{2}{*}{$\mathrm{CV}(\%)$} \\
\hline & & $34 / 08$ & $16 / 07$ & $13 / 08$ & $27 / 07$ & & & \\
\hline $\mathrm{C}_{\max }$ & $\mu \mathrm{g} / \mathrm{mL}$ & 10.00 & 13.40 & 14.00 & 13.10 & 12.52 & 1.79 & 14.29 \\
\hline $\mathrm{T}_{\max }$ & $\mathrm{h}$ & 9.00 & 12.00 & 7.00 & 12.00 & 9.76 & 2.45 & 25.10 \\
\hline AUClast & $\mu \mathrm{g} / \mathrm{mL}^{*} \mathrm{~h}$ & 737.40 & 891.90 & 814.90 & 876.05 & 827.78 & 70.13 & 8.47 \\
\hline $\mathrm{AUC}_{\mathrm{inf}}$ & $\mu \mathrm{g} / \mathrm{mL}^{*} \mathrm{~h}$ & 893.75 & 1108.75 & 970.45 & 1071.57 & 179.20 & 97.67 & 16.90 \\
\hline$\lambda$ & $\mathrm{h}^{-1}$ & 0.02 & 0.01 & 0.02 & 0.01 & 0.01 & 0.00 & 5.26 \\
\hline $\mathrm{AUMC}_{\text {last }}$ & $\mu \mathrm{g} / \mathrm{mL}^{*} \mathrm{~h}^{2}$ & 33811 & 40339 & 34112 & 38404 & 36561 & 3224 & 8.82 \\
\hline$T_{\text {half }}$ & $\mathrm{h}$ & 44.58 & 49.98 & 45.27 & 47.96 & 46.90 & 2.49 & 5.32 \\
\hline MRT & $\mathrm{h}$ & 70.07 & 73.95 & 64.85 & 70.36 & 69.73 & 3.75 & 5.37 \\
\hline $\mathrm{Cl} / \mathrm{F}$ & $\mathrm{L} / \mathrm{kg} * \mathrm{~h}$ & 0.00 & 0.00 & 0.00 & 0.00 & 0.00 & 0.00 & 9.92 \\
\hline $\mathrm{V}_{\mathrm{z}} / \mathrm{F}$ & $\mathrm{L} / \mathrm{kg}$ & 0.22 & 0.20 & 0.20 & 0.19 & 0.20 & 0.01 & 5.03 \\
\hline $\mathrm{V}_{\text {ss }} / \mathrm{F}$ & $\mathrm{L} / \mathrm{kg}$ & 0.24 & 0.20 & 0.20 & 0.20 & 0.21 & 0.02 & 8.71 \\
\hline
\end{tabular}


Supplementary Table 2: Mean tissue concentrations ( $\mathrm{mg} / \mathrm{kg}$ ) of carprofen from three samples from four female Friesian Bos taurus cattle (9 months of age) treated with Norocarp at $2.8 \mathrm{mg} / \mathrm{kg}$ body weight. Also shown are the arithmetic means and standard deviations (SD) of the animal means and maximum residue exposure (MRE).

\begin{tabular}{|c|c|c|c|c|c|c|c|c|}
\hline \multirow{2}{*}{ Tissue } & \multicolumn{4}{|c|}{ Cow Code } & \multirow{2}{*}{ Mean } & \multirow{2}{*}{ SD } & \multirow{2}{*}{ CV $(\%)$} & \multirow{2}{*}{$\begin{array}{c}\text { Maximum } \\
\text { Residue } \\
\text { Exposure }\end{array}$} \\
\hline & 1356 & 1357 & 1342 & 1343 & & & & \\
\hline Liver & 4.04 & 7.58 & 5.25 & 6.12 & 5.75 & 1.49 & 25.91 & 13.41 \\
\hline Fat (omental) & 2.19 & 3.58 & 1.87 & 7.32 & 3.74 & 2.50 & 66.84 & 16.59 \\
\hline Muscle at injection site & 54.19 & 29.98 & 559.58 & 511.50 & 289.05 & 286.05 & 98.96 & 1759.98 \\
\hline
\end{tabular}

The maximum residue exposure (MRE) was calculated at the 95\% upper population tolerance at 95\% confidence as per the regulatory standard (EUDRALEX) 
Supplementary Table 3: Carprofen dose and exposure to Gyps vultures in Phase 1 (kidney) and Phase 2 (muscle) of the toxicity study. Also shown are individual codes, vulture body weights, amount of tissue consumed and concentration of carprofen used to calculate dose and exposure.

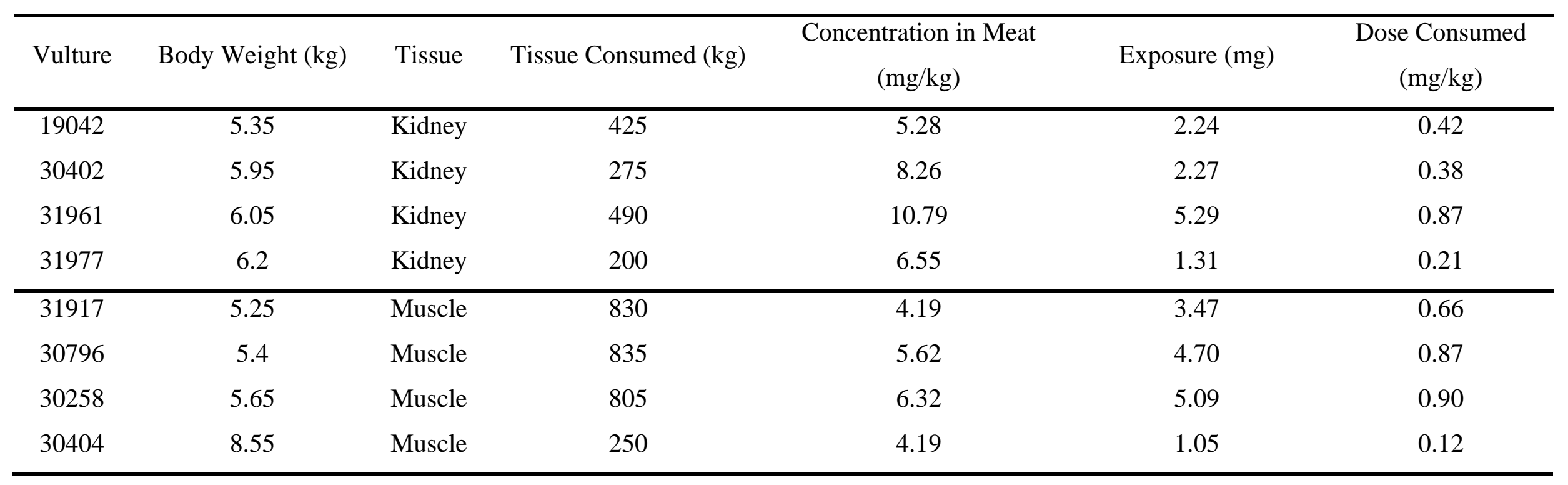


Supplementary Table 4: Carprofen dose and exposure to Gyps vultures in Phase 3 (dose $=4.4 \mathrm{mg} / \mathrm{kg}$ ) and Phase 4 (64 mg/kg) of the toxicity study. Also shown are individual codes and vulture body weights.

\begin{tabular}{ccccc}
\hline Vulture & Body Weight $(\mathrm{kg})$ & Dose Given $(\mathrm{mg} / \mathrm{kg})$ & Phase & Exposure $(\mathrm{mg})$ \\
\hline G31917 & 5.25 & 4.4 & 3 & 23.1 \\
G31977 & 6.2 & 4.4 & 3 & 27.28 \\
G30258 & 5.65 & 4.4 & 3 & 24.86 \\
G30404 & 8.55 & 4.4 & 3 & 37.62 \\
G19042 & 5.35 & 4.4 & 3 & 23.54 \\
G30402 & 5.95 & 4.4 & 4 & 26.18 \\
G30796 & 5.4 & 64 & 345.6 \\
G31961 & 6.05 & 64 & 387.2 \\
\hline Vultures G19042, G30402, G31977, G31917, G30258 \& G30404 were adults (older than 5 years); while G31961, G30796 were juvenile (approximately 1 year of age)
\end{tabular}


Supplementary Table 5: Descriptive statistics for biochemical parameters from samples of Gyps vulture plasma collected in the absence and presence of carprofen. Parameters in the absence of carprofen were obtained from the control groups and samples evaluated prior to treatment from the descriptive pharmacokinetic phase of the study.

\begin{tabular}{|c|c|c|c|c|c|c|c|c|c|c|c|}
\hline \multirow{2}{*}{ Parameter } & \multirow{2}{*}{ Unit } & \multicolumn{5}{|c|}{ In the absence of carprofen } & \multicolumn{5}{|c|}{ In the presence of carprofen } \\
\hline & & $n$ & Mean & SD & Min & $\operatorname{Max}$ & $n$ & Mean & SD & Min & Max \\
\hline Uric Acid & $\mathrm{mmol} / \mathrm{L}$ & 26 & 0.20 & 0.09 & 0.08 & 0.54 & 15 & 0.23 & 0.09 & 0.12 & 0.44 \\
\hline ALP & $\mathrm{U} / \mathrm{L}$ & 26 & 29.15 & 17.13 & 1.00 & 59.00 & 14 & 29.71 & 10.96 & 17.00 & 50.00 \\
\hline $\mathrm{Na}$ & $\mathrm{mmol} / \mathrm{L}$ & 25 & 147.63 & 2.40 & 144.00 & 152.40 & 14 & 146.90 & 2.71 & 141.40 & 151.40 \\
\hline
\end{tabular}


Figure 1: Change in concentrations of uric acid (A), ALT (B), ALP (C) and potassium (D) concentrations in the two bird exposed to carprofen at $64 \mathrm{mg} / \mathrm{kg}$. Bird G31961 (triangle) died from exposure

Figure 2: Histopathology slide from the bird that died. Evident are widespread dilation of tubules with loss of the cuboidal lining cells and replacement with an amorphous pink material in which pyknotic cell debris was entrapped

Figure 3: Plasma concentration versus time profile for the two birds treated with carprofen at $64 \mathrm{mg} / \mathrm{kg}$

Figure 4: Illustration of the individual variability in oral bioavailability. In all case the plasma concentration versus time profiles have been equalized to $4.4 \mathrm{mg} / \mathrm{kg}$, the lowest dose administered. Bird 31917 (A), which was dosed intramuscular (5mg/kg, before equalization) and orally $(4.4 \mathrm{mg} / \mathrm{kg}$ ) had a fraction of absorption of approximately $27.84 \%$; while bird 30796 (B) dosed intramuscular (5mg/kg, before equalization) and orally (64 mg/kg, before equalization) had a fraction of absorption of only $8 \%$.

Supplementary Figure 1: Individual (A) and arithmetic mean (B) plasma concentration versus time profiles for the cattle treated with carprofen at $1.4 \mathrm{mg} / \mathrm{kg}$

Supplementary Figure 2: Plasma concentration versus time profile for birds exposed to carprofen $(5 \mathrm{mg} / \mathrm{kg}$ ) by the iv (A), oral (B) or intramuscular route (C)

Supplementary Figure 3: Individual (A) and arithmetic mean (B) plasma concentration versus time profiles for the vultures treated with carprofen at $4.4 \mathrm{mg} / \mathrm{kg}$ by the oral route $(n=6)$ 


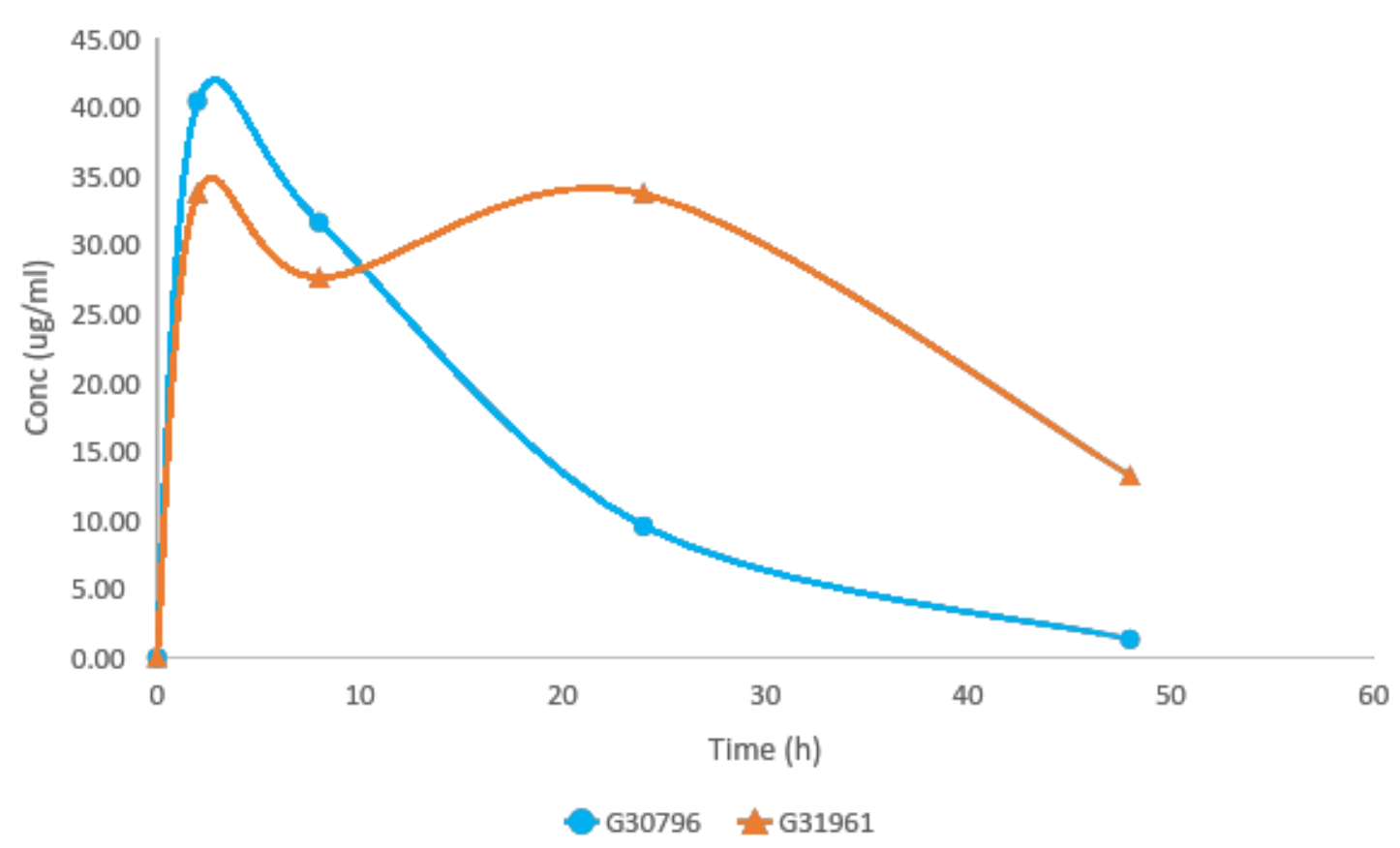

Figure 3: Plasma concentration versus time profile for the two birds treated with carprofen at $64 \mathrm{mg} / \mathrm{kg}$ 

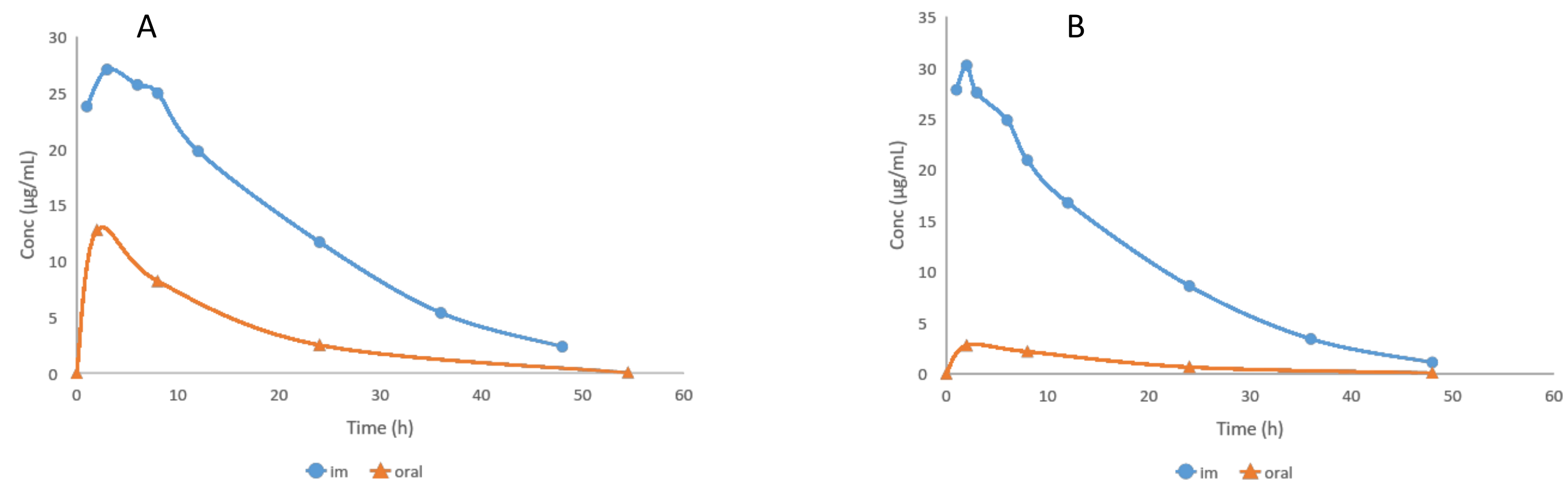

Figure 4: Illustration of the individual variability in oral bioavailability. In all case the plasma concentration versus time profiles have been equalized to 4.4. $\mathrm{mg} / \mathrm{kg}$, the lowest dose administered. Bird 31917 (A), which was dosed intramuscular $(5 \mathrm{mg} / \mathrm{kg}$, before equalization) and orally $(4.4 \mathrm{mg} / \mathrm{kg})$ had a fraction of absorption of approximately 27.84\%; while bird 30796 (B) dosed intramuscular (5mg/kg, before equalization) and orally (64 mg/ $\mathrm{kg}$, before equalization) had a fraction of absorption of only $8 \%$. 
A

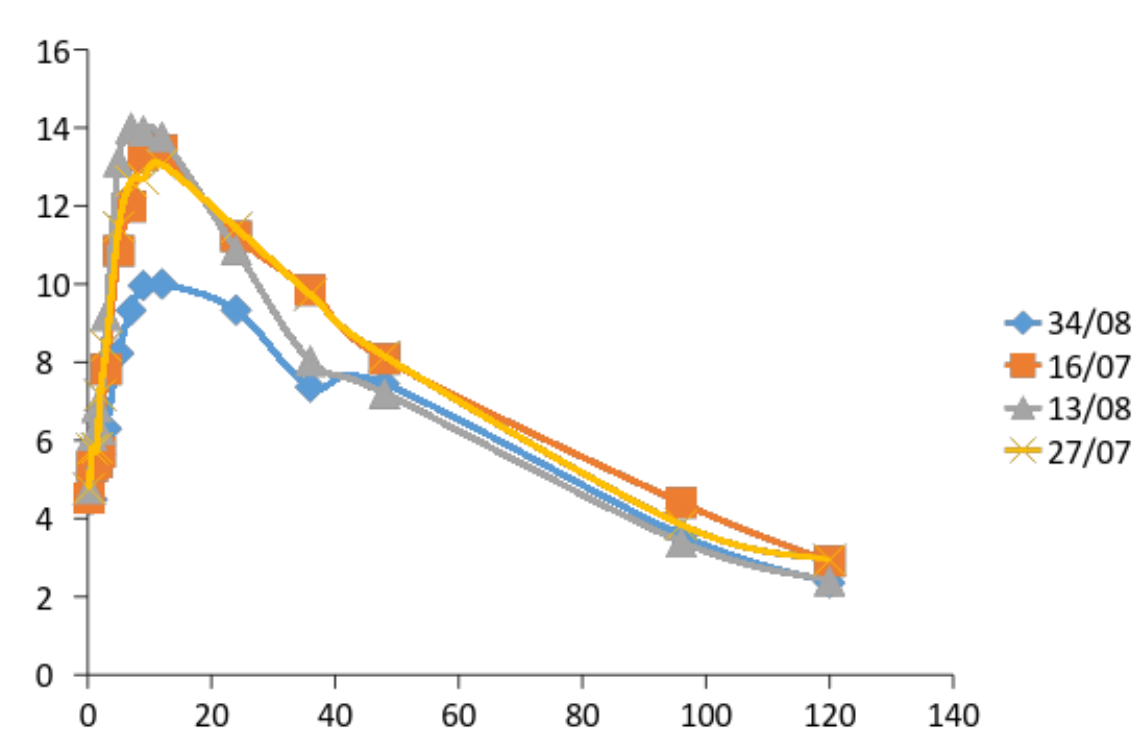

B

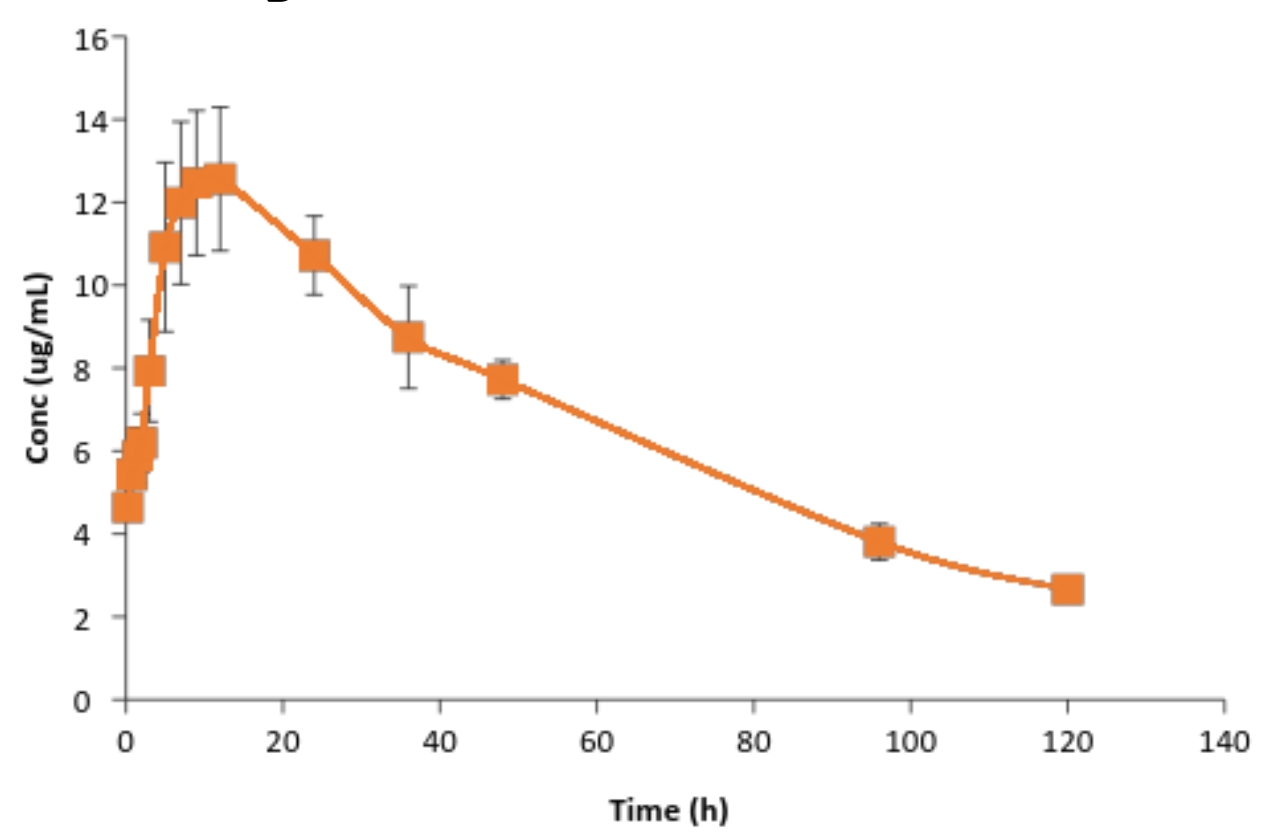

Supplementary Figure 1: Individual (A) and arithmetic mean (B) plasma concentration versus time profiles for the cattle treated with carprofen at $1.4 \mathrm{mg} / \mathrm{kg}$ 
A

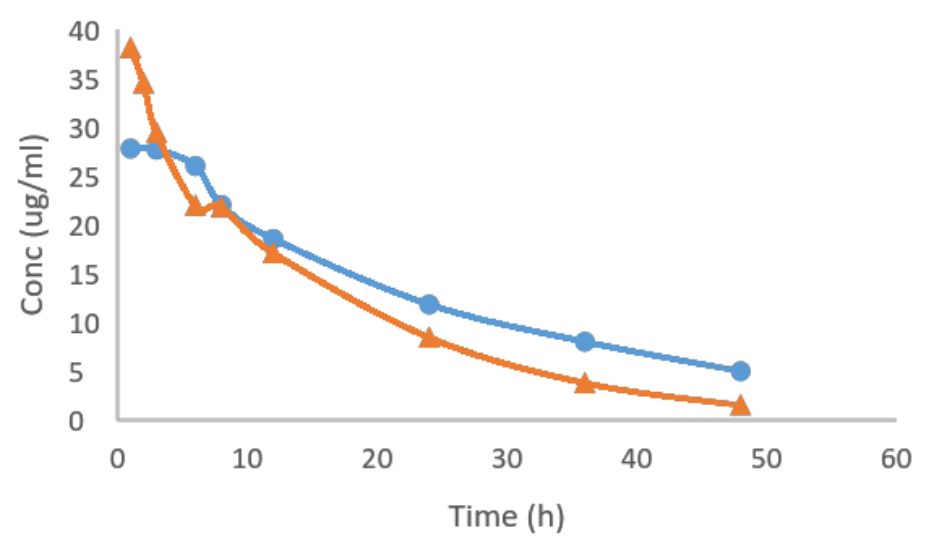

G31980 $₫ \mathrm{G} 31943$
B

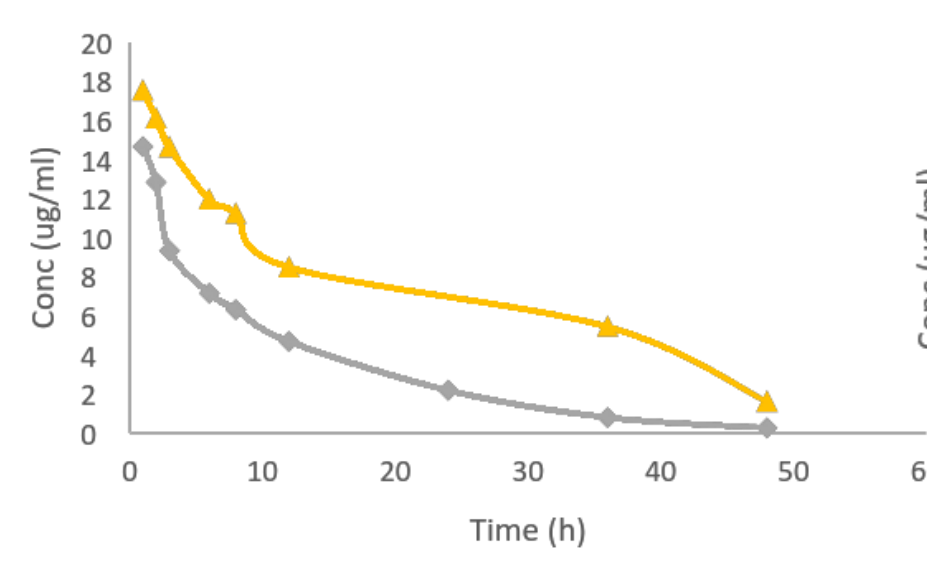

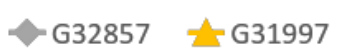

C

im

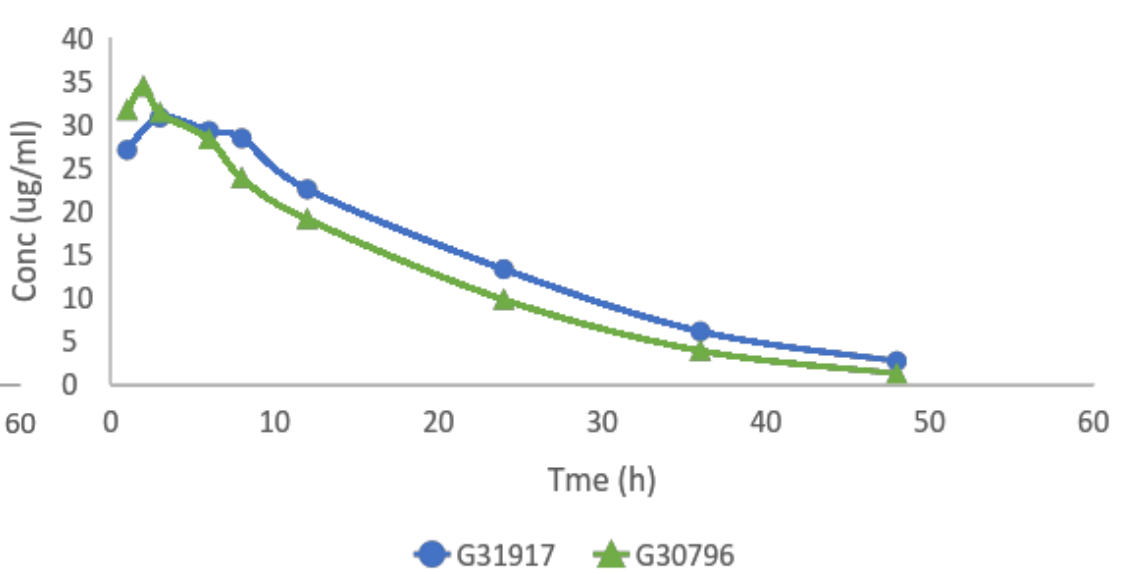

Supplementary Figure 2: Plasma concentration versus time profile for birds exposed to carprofen (5mg/kg) by the iv (A), oral (B) or intramuscular route (C) 

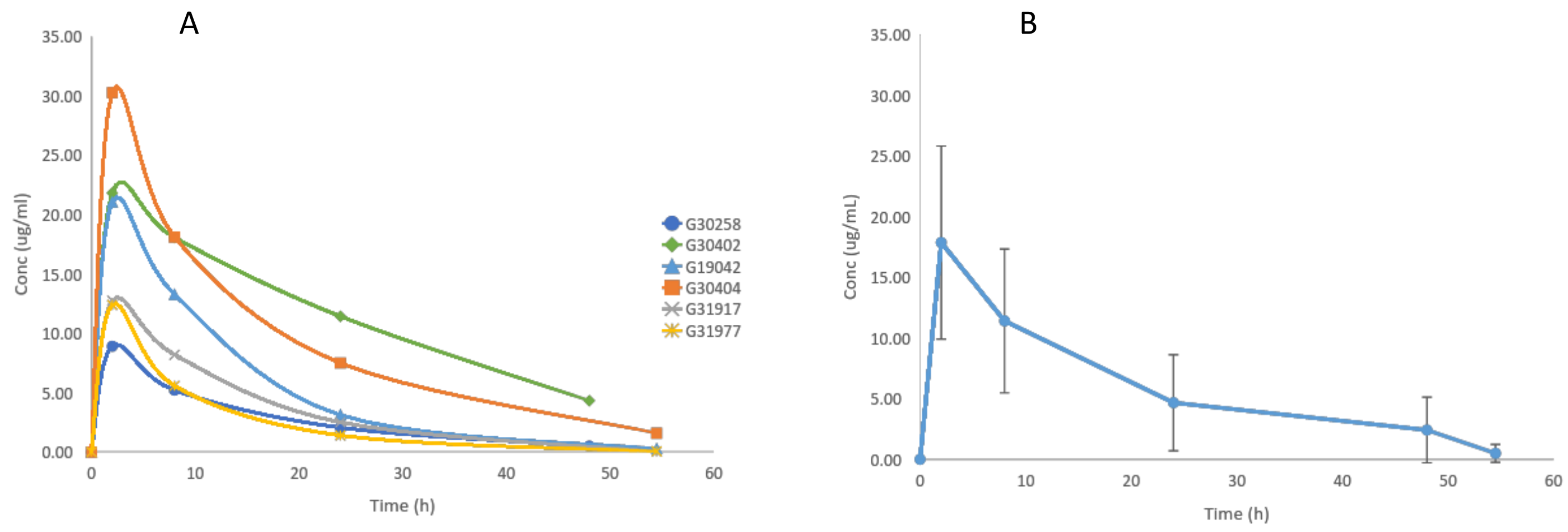

Supplementary Figure 3: Individual (A) and arithmetic mean (B) plasma concentration versus time profiles for the vultures treated with carprofen at $4.4 \mathrm{mg} / \mathrm{kg}$ by the oral route $(n=6)$ 